\title{
Enteric Methane Emission from Pigs
}

\author{
Henry Jørgensen, Peter K. Theil and Knud Erik Bach Knudsen \\ Aarhus University, Faculty of Science and Technology \\ Denmark
}

\section{Introduction}

The modern pig industry rely on relatively few feedstuffs mostly from cereals (corn, wheat, barley, oats, rye and rice), cereal co-products (different milling fractions, residues from biofuel and alcohol industries, etc.), cereal substitutes (tapioca, maniocca), legumes (peas, beans, lupins), protein concentrates (meal or cakes of soybean, rape, sunflower, cotton) and co-products from the sugar and starch industries to produce compounds feeds. The classical pig diet can also be characterised as relatively concentrated but an increased demand of high energy cereals for direct human use and increased availability of fibre rich ingredients from, for instance, the feed milling or starch extraction/fermentation industries have promoted an increased utilisation of fibre rich co-products in the pig feeds (Serena et al. 2007). Especially pregnant sows may be supplied with fibre rich diets without compromising their reproductive performance. The direct use of forage crop is also developing although at a rather limited scale and primarily in organic farming. Other benefits, such as increased well being of animals, improvement of the gut transit or reduction of stomach ulcers also favour an increased utilisation of fibre rich ingredients in pig feeds. An increased dietary fibre concentration is on the other hand associated with reduced available energy content of the diet if not combined with high energy ingredients such as animal fat or vegetable oil. The consequence is that the amount of feed required per $\mathrm{kg}$ meat produced is increased (Fernández et al. 1983; Lekule et al. 1990).

The present chapter will summarise our current knowledge concerning dietary and enteric fermentation that may influence the methane $\left(\mathrm{CH}_{4}\right)$ emission in pigs. Enteric fermentation is the digestive process by which carbohydrates are broken down by microorganisms into simple molecules for absorption into the blood stream of the animal. The data compilation is based on all experiments carried out in the respiration chambers at Research Centre Foulum during the last 20 years. It should, however, be stressed that none of the studies were specifically designed to investigate dietary or enteric pig factors that may influence the $\mathrm{CH}_{4}$ emission.

The data used in the chapter is based on Danish pigs with reference to other European studies. In a global context Denmark's 12 million pigs (FAOSTAT, 2009) contribute with 1.3 $\%$ of the worlds pig population. The main number of pigs is in Asia (59.6 \%) where the main pig population stay in China (47.8\% of the worlds pig population).

The objective of the chapter is therefore:

To obtain a general overview of the pigs' contribution to methane emission. 
Where is the pigs' enteric gas produced and how is it measured.

The variation in methane emission and factors affecting the emission.

Possibility for reducing the enteric methane emission and the consequences.

\section{Sites for enteric gas production}

The majority of carbohydrates are digested by endogenous enzymes in the small intestine but the dietary fibre fraction will be fermented primarily in the lower gut resulting in production of short chain fatty acids (acetic-, propionic- and butyric acid), gases (carbon dioxide $\left(\mathrm{CO}_{2}\right)$, hydrogen $\left(\mathrm{H}_{2}\right)$ and methane $\left.\left(\mathrm{CH}_{4}\right)\right)$, urea and heat. However, the stomach and small intestine is also colonised by microorganism, which lead to production of primarily $\mathrm{H}_{2}$. This is illustrated in Figure $1 \mathrm{~A} \& \mathrm{~B}$ that shows the results from a study in which the gas concentration has been measured at 12 sites of the gastrointestinal tracts (Figure 1A) after feeding a low and high fibre diet with 6 and $27 \%$ dietary fibre per $\mathrm{kg}$ DM, respectively (Jensen \& Jørgensen, 1994).

A

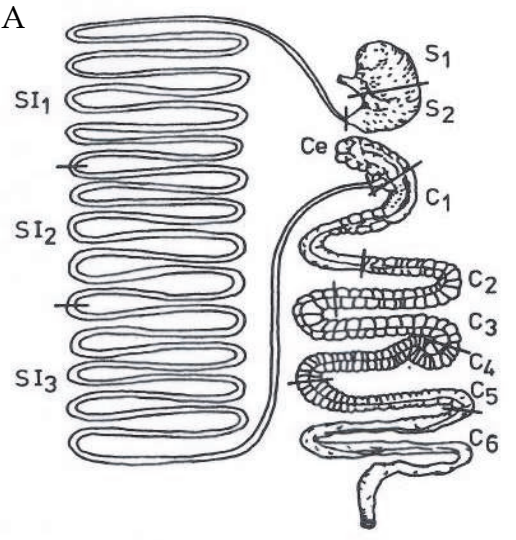

B

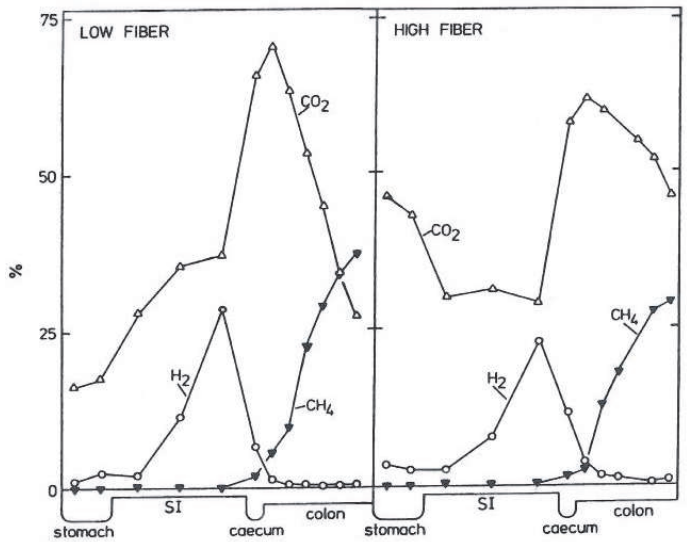

Fig. 1. Sampling sites in the gastrointestinal tract. SI, small intestine; S, stomach, Ce, caecum; $\mathrm{C}$, colon. (A). Composition of gases from various regions of the gastrointestinal tract of pigs fed the low- and high-fiber diets (B). Data from Jensen \& Jørgensen (1994).

The gas composition in the various segments shows similar trends for the two groups of pigs (Figure 1B). In both groups, low levels of $\mathrm{H}_{2}$ were detected in the gas from the stomach, followed by a steady increase along the small intestine reaching a maximum (21 to $28 \%$ ) in the last third of the small intestine. Gas from the caecum and the first segment from the large intestine also contained substantial amounts of $\mathrm{H}_{2}$, while the amounts of gas from the other segments of the large intestine were small in spite of the fact that hydrogen production is an obligate part of anaerobic fermentation (Miller \& Wolin, 1974; Jensen, 1996). The produced short chain fatty acids can be utilised as an energy source and contributes with a significant part of energy for maintenance (Jørgensen et al. 1997). From an energy point of view, only $\mathrm{CH}_{4}$ and $\mathrm{H}_{2}$ are important as they correspond to combustible gases and represent a loss of energy. However, information on how dietary composition and intrinsic animal 
factors influence gas production in pigs is rather limited. From an environmental point of view $\mathrm{CH}_{4}$ is of great interest as it is the major contributor to the greenhouse gas emission. Carbon dioxide emission from livestock is assumed to be zero. The CO2 from the atmosphere used by plant photosynthesis is returned to the atmosphere as expired $\mathrm{CO} 2$ (IPCC, 2006). Therefore, the enteric CO2 production by animals can be regarded as neutral. However, a part of the $\mathrm{C}$ is returned as $\mathrm{CH}_{4}$ and therefore requires separate considerations. Methane is a very potent greenhouse gas that contributes to the global warming and $\mathrm{CH}_{4}$ is 21 times more potent than $\mathrm{CO}_{2}$.

A recent Danish inventory of $\mathrm{CH}_{4}$ emission from livestock enteric fermentation and manure management show that cattle contribute with $86 \%$ of the enteric emission and the pig production with $10 \%$ and horses with $3 \%$ (Mikkelsen et al. 2011). The manure handling contributes with $30 \%$ of the total $\mathrm{CH}_{4}$ emission from livestock in Denmark and the distribution between pig and cattle manure is 45 and $50 \%$, respectively. The remaining part is attributed to the other animal species.

Carbon dioxide $\left(\mathrm{CO}_{2}\right)$ is produced in all living cells and can be regarded as a waste product when nutrients (carbohydrates, fat and proteins) are oxidised. As an example, glucose is oxidised completely, and quantitatively the stochiometry for glucose oxidation is (Stryer, 1988):

$$
\mathrm{C}_{6} \mathrm{H}_{12} \mathrm{O}_{6}+6 \mathrm{O}_{2} \rightarrow 6 \mathrm{CO}_{2}+6 \mathrm{H}_{2} \mathrm{O}
$$

The produced $\mathrm{CO}_{2}$ is then transported from the cells (organs) via blood either as dissolved $\mathrm{CO}_{2}$, bound to haemoglobin or as bicarbonate to the lungs. I the lungs, $\mathrm{CO}_{2}$ is being transferred to alveolar air and then expired during exhalation. The amount of $\mathrm{CO}_{2}$ produced by an animal depends to a large extent on the live weight, physiological state, feed intake and physical activity of the animal, whereas the composition of the feed supplied plays a minor role (Just et al. 1983, Noblet and Shi 1994, Jørgensen et al. 1996, Jørgensen 1997, Schrama et al. 1998, Jørgensen et al. 2001, Theil et al. 2002, Theil et al. 2004, Pedersen et al., 2008, Jentsch et al. 2009).

\section{Measurement of enteric methane and data description}

\subsection{Measurement of methane and carbon dioxide production}

The respiration chambers consist of climatic controlled airtight rooms where the animals' energy metabolism can be measured as illustrated in Figure 2. The measured parameters are heat production and the animals' consumption of oxygen and production of carbon dioxide, $\mathrm{CH}_{4}$ and $\mathrm{H}_{2}$. The technique applied is the so called indirect principle which means that the atmospheric air is ventilated through the chambers and the amount of air is measured together with the concentration of oxygen, carbon dioxide, methane and hydrogen in both in-going and out-going air (Jørgensen, 2001; Jørgensen et al. 1996). When the consumed amount of oxygen and produced amount of carbon dioxide and methane is known, the heat production can be calculated (Christensen \& Thorbek, 1987; Jakobsen et al. 2005).

In most cases both nitrogen $(\mathrm{N})$ and energy balances have been performed. In brief, a typical balance experiment comprises a total period of 12 days, including 5-7 days for adaptation to the feed, metabolic cage and environmental conditions. Daily faeces and urine are collected quantitatively during the last 5-7 days as described by Just et al. (1983). During the collection 
period, the metabolic cage with the pigs is placed in the respiration chambers and the amount of $\mathrm{CH}_{4}, \mathrm{CO}_{2}$ and $\mathrm{H}_{2}$ produced and oxygen $\left(\mathrm{O}_{2}\right)$ consumed is measured and heat production is calculated during $2 \times 24 \mathrm{~h}$ periods.

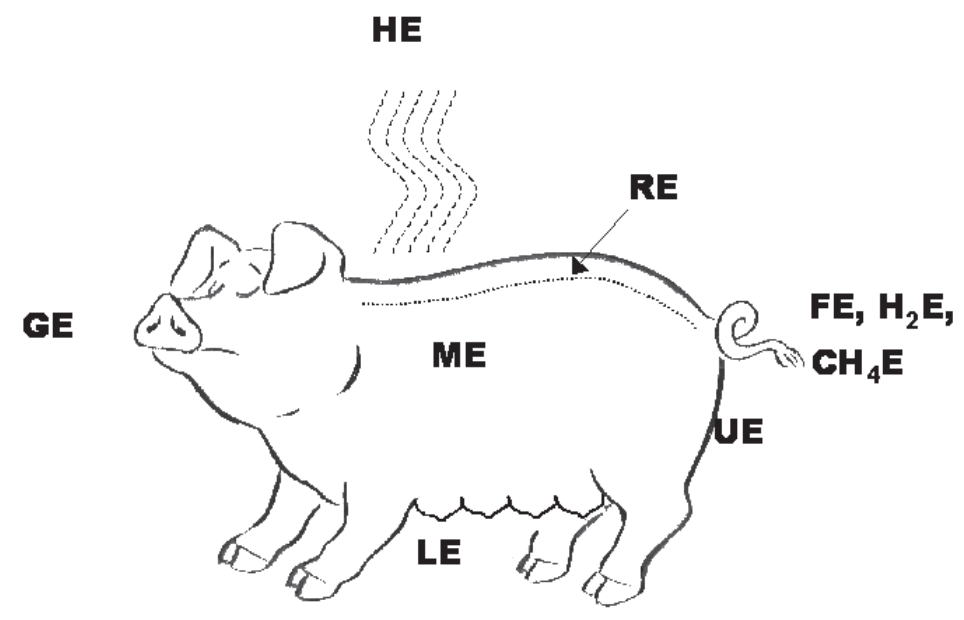

Fig. 2. Illustration of energy flow in a pig: GE, total gross energy intake; ME, metabolizable energy (energy available for metabolism); HE, heat energy - energy lost as heat; RE, retained energy, LE, lactation energy; $\mathrm{UE}$, urine energy; $\mathrm{FE}$, faecal energy; $\mathrm{H}_{2} \mathrm{E}$, hydrogen energy; $\mathrm{CH}_{4} \mathrm{E}, \mathrm{CH}_{4}$ energy.

\subsection{Overview of data}

The respiration chamber was established at Research Centre Foulum in 1990 and numerous experiments have been carried out on growing - finishing pigs from 30 - $150 \mathrm{~kg}$ live weight. Other experiments with sows at different physiological stages (dry, pregnant and lactating sows including suckling piglets) have been carried out. In order to measure suckling piglets without contribution of the lactating sow, experiments have been carried out where milk replacer has been fed to the piglets.

The whole dataset (Table 1) comprises one experiment with piglets fed with milk replacer and a total of 16 experiments with growing pigs covering the weight range $25-150 \mathrm{~kg}$ live weight and 9 experiments with adult sows either dry, pregnant or lactating sows (including the litter). The main purpose of the various experiments has been influence/effect on the energy utilization of different diets or treatments. In Table 2 is shown the mean of 140 diets/treatments, which are based on 783 measurements of energy balance.

\subsection{Presentation of results - expression of methane emission}

Methane emission is in literature expressed in different ways. It is not only an animal's daily production that is of interest but also the emission relative to amount of feed ingested (in $\mathrm{kg}$ or energy equivalent or amount of fermentation substrates). 


\begin{tabular}{|c|c|c|c|c|c|}
\hline Study / Reference & Diets, $\mathrm{g} / \mathrm{kg}$ DM & $\begin{array}{c}\text { Balance, } \\
\mathrm{n}\end{array}$ & $\begin{array}{l}\mathrm{LW} \\
\mathrm{kg}\end{array}$ & $\begin{array}{l}\mathrm{CH}_{4} \\
\mathrm{~L} / \mathrm{d}\end{array}$ & $\begin{array}{l}\mathrm{CO}_{2} \\
\mathrm{~L} / \mathrm{d}\end{array}$ \\
\hline \multicolumn{6}{|l|}{ Piglets } \\
\hline Theil et al. 2007 & Milk & 12 & 4.9 & 0.13 & 94 \\
\hline \multicolumn{6}{|l|}{ Growing pigs } \\
\hline Jørgensen et al. 1996 & $28-266 \mathrm{DF}$ & 24 & 81 & 6.7 & 991 \\
\hline Bornholt et al. unpublished & $60-318 \mathrm{DF}$ & 28 & 67 & 3.2 & 637 \\
\hline Jørgensen et al. 1997 & Infusion SCFA & 86 & 92 & 1.0 & 825 \\
\hline Jørgensen et al 1996 & 36-207 Fat & 48 & 52 & 3.2 & 621 \\
\hline Jørgensen 1997 & $55-143 \mathrm{DF}$ & 30 & 60 & 2.6 & 708 \\
\hline Jørgensen unpublished ${ }^{1}$ & $197-204 \mathrm{DF}$ & 24 & 68 & 3.4 & 834 \\
\hline Jørgensen et al. unpublished & 123-156 DF & 24 & 65 & 1.0 & 796 \\
\hline Jørgensen et al. 2001 & $192-311 \mathrm{DF}$ & 27 & 63 & 4.1 & 742 \\
\hline Carlson et al. 1999 & 247-303 DF & 48 & 64 & 4.6 & 710 \\
\hline Theil et al. 20012 & Breed*Temp & 42 & 77 & 3.1 & 737 \\
\hline Wang et al. 2002 & 76-167 DF & 48 & 51 & 3.6 & 824 \\
\hline Jørgensen unpublished & 31-166 Fat & 30 & 50 & 1.4 & 654 \\
\hline Jørgensen et al. unpublished & $155-184 \mathrm{DF}$ & 56 & 83 & 2.8 & 829 \\
\hline Jørgensen et al. unpublished ${ }^{3}$ & 197-197 DF & 16 & 77 & 4.4 & 897 \\
\hline Jørgensen et al. unpublished & 165-290 DF & 16 & 90 & 6.4 & 856 \\
\hline Serena et al. 2007 & 223-536 DF & 37 & 61 & 3.7 & 989 \\
\hline \multicolumn{6}{|l|}{ Adult sows } \\
\hline Olesen et al. 2001 & 193-409 DF & 16 & 290 & 13.6 & 1406 \\
\hline Theil et al. 2004 & 199-339 DF & 36 & 230 & 7.5 & 1226 \\
\hline Jørgensen unpublished & $186-374 \mathrm{DF}$ & 9 & 231 & 8.2 & 1050 \\
\hline Jørgensen et al. 2010 & 164-294 DF & 24 & 210 & 5.7 & 1198 \\
\hline Theil et al. 2002 & $173-229 \mathrm{DF}$ & 9 & 209 & 5.4 & 1287 \\
\hline Theil et al. 2004 & 31-113 Fat & 25 & 206 & 14.4 & 1762 \\
\hline Jørgensen unpublished & $308-536$ DF & 18 & 212 & 9.9 & 1108 \\
\hline Serena et al. 2009 & 249-536 DF & 32 & 214 & 12.2 & 1084 \\
\hline Jørgensen unpublished & 189-447 DF & 18 & 208 & 12.0 & 1077 \\
\hline
\end{tabular}

Table 1. Description of data. 1) Environmental temperature $x$ dietary protein. 2) Breed of pigs $x$ environmental temperature. 3) Feed particle sixe. DF, dietary fibre. SCFA, short chain fatty acids; Fat, dietary fat. 


\begin{tabular}{|c|c|c|c|c|}
\hline Item & $\mathrm{n}$ & Mean & $\begin{array}{c}\text { Range of } \\
\text { values }\end{array}$ & $\begin{array}{l}\text { Standard } \\
\text { deviation }\end{array}$ \\
\hline \multicolumn{5}{|l|}{ Chemical composition } \\
\hline Crude protein, g/kg DM & 140 & 177 & $98-239$ & 27 \\
\hline Crude fat, g/kg DM & 140 & 69 & $26-257$ & 42 \\
\hline Starch, g/kg DM & 140 & 435 & $92-706$ & 117 \\
\hline Total sugars, g/kg DM & 103 & 45 & $13-220$ & 33 \\
\hline Crude fibre, g/kg DM & 54 & 85 & $13-266$ & 54 \\
\hline Total dietary fibre, $\mathrm{g} / \mathrm{kg} \mathrm{DM}$ & 140 & 215 & $0-536$ & 113 \\
\hline \multicolumn{5}{|l|}{ Main results, piglets } \\
\hline Live weight, kg & 3 & 4.9 & $3.9-6.0$ & 1.1 \\
\hline DM intake, $\mathrm{kg} / \mathrm{d}$ & 3 & 0.18 & $0.14-0.21$ & 0.03 \\
\hline $\mathrm{CO}_{2}, \mathrm{~L} / \mathrm{d}$ & 3 & 94 & $74-115$ & 21 \\
\hline $\mathrm{CH}_{4}, \mathrm{~L} / \mathrm{d}$ & 3 & 0.13 & $0.11-0.15$ & 0.02 \\
\hline Total fibre fermented, $\%$ & 3 & 0 & $0-0$ & 0 \\
\hline Total fermentable fibre, $\mathrm{g} / \mathrm{d}$ & 3 & 0 & $0-0$ & 0 \\
\hline DC energy, \% & 3 & 98 & $98-98$ & 0.3 \\
\hline $\mathrm{CH}_{4}$-energy, \% GE & 3 & 0.12 & $0.11-0.14$ & 0.02 \\
\hline $\mathrm{CH}_{4}$-energy, \% DE & 3 & 0.13 & $0.11-0.14$ & 0.02 \\
\hline \multicolumn{5}{|l|}{ Main results, growing pigs } \\
\hline Live weight, $\mathrm{kg}$ & 101 & 67 & $25-152$ & 24 \\
\hline DM intake, $\mathrm{kg} / \mathrm{d}$ & 101 & 1.77 & $0.87-3.06$ & 0.45 \\
\hline $\mathrm{CO}_{2}, \mathrm{~L} / \mathrm{d}$ & 101 & 767 & $368-1350$ & 192 \\
\hline $\mathrm{CH}_{4}, \mathrm{~L} / \mathrm{d}$ & 101 & 3.4 & $0.28-12.1$ & 2.2 \\
\hline Total fibre fermented, $\%$ & 101 & 56 & $32-86$ & 12 \\
\hline Total fermentable fibre, $\mathrm{g} / \mathrm{d}$ & 101 & 182 & $26-455$ & 93.4 \\
\hline DC energy, $\%$ & 101 & 84 & $60-99$ & 6.9 \\
\hline $\mathrm{CH}_{4}$-energy, \% GE & 101 & 0.39 & $0.03-1.07$ & 0.22 \\
\hline $\mathrm{CH}_{4}$-energy, \% DE & 101 & 0.47 & $0.03-1.29$ & 0.28 \\
\hline \multicolumn{5}{|l|}{ Main results, adult sows } \\
\hline Live weight, $\mathrm{kg}$ & 36 & 224 & $192-298$ & 27 \\
\hline DM intake, $\mathrm{kg} / \mathrm{d}$ & 36 & 2.20 & $1.48-4.87$ & 0.80 \\
\hline $\mathrm{CO}_{2}, \mathrm{~L} / \mathrm{d}$ & 36 & 1213 & $976-1837$ & 220 \\
\hline $\mathrm{CH}_{4}, \mathrm{~L} / \mathrm{d}$ & 36 & 9.8 & $3.2-28.7$ & 5.6 \\
\hline Total fibre fermented, $\%$ & 36 & 62 & $30-87$ & 13 \\
\hline Total fermentable fibre, $\mathrm{g} / \mathrm{d}$ & 36 & 417 & $150-999$ & 191.4 \\
\hline DC energy, \% & 36 & 78 & $49-85$ & 7.9 \\
\hline $\mathrm{CH}_{4}$-energy, \% GE & 36 & 1.01 & $0.29-2.69$ & 0.62 \\
\hline $\mathrm{CH}_{4}$-energy, \% DE & 36 & 1.31 & $0.40-3.25$ & 0.78 \\
\hline
\end{tabular}

Table 2. Chemical composition of diets (mean of 140) and main results for the three classes of pigs: piglets, growing pigs and adult sows. 
Total dietary fibre, calculated as the residual fraction after subtraction of the analysed content of sugars, starch, crude protein, crude fat and ash from the dry matter content. DC, digestibility coefficient; GE, gross energy; DE, digestible energy.

Thus to aid in presentation of the presented results in this chapter and also in comparing to other literature sources the following expression of methane emission is used: 1 . Litre per day, which is the results measured. 2. Litre per kg dry matter (DM) or gross energy (GE) intake as not only the live weight $(\mathrm{kg})$ of an animal is important but also the amount of substrate for fermentation. 3. Methane emission expressed per $\mathrm{g}$ fermented fibre. 4 . Finally methane is also expressed per unit of digestible energy (DE) because it may be more relevant to relate the methane production to the amount of energy needed for animal production.

In the ICPP (2006) guidelines for national greenhouse gas inventories and the Danish emission inventory for agriculture (Mikkelsen et al. 2011), the $\mathrm{CH}_{4}$ conversion rate expressed as $\mathrm{Y}_{\mathrm{m}}=\mathrm{CH}_{4}$-energy in \% of gross energy (GE) for calculating the total amount of $\mathrm{CH}_{4}$ in $\mathrm{Gg}$ is used.

\section{Dietary and intrinsic factors influencing methane emission}

\subsection{The variation in the chemical composition of feed and main results}

Chemical composition of diets and main results are presented in Table 2. In total, $\mathrm{CH}_{4}$ excretion amounted from $0.1 \mathrm{~L} /$ day with piglets reared artificially to $28.7 \mathrm{~L} /$ day corresponding to nearly zero at the lowest value to $3.3 \%$ of digested energy (DE). This is of similar magnitude as reported by Jentsch et al. (2007) for female calves (50-75 kg body weight) but much lower than reported for ruminants where the loss as fermentation of $\mathrm{CH}_{4}$ can be as high as 9-13\% of digestible energy (DE) (Johnson \& Johnson, 1995).

\subsection{Correlation between variables}

The correlation between dietary characteristic and production of $\mathrm{CH}_{4}$ and $\mathrm{CO}_{2}$ is presented in Table 3. As expected there was a negative correlation between $\mathrm{CH}_{4}$ and dietary protein, dietary fat and dietary starch and positive correlations to the fibre fractions. The highest correlation to the daily $\mathrm{CH}_{4}$ excretion is found for fermented fibre per $\mathrm{kg}$ DM intake $(\mathrm{r}=0.86)$ as illustrated in Figure 3.

\begin{tabular}{|l|c|c|c|c|c|c|c|}
\hline & \multicolumn{3}{|c|}{$\mathrm{g} / \mathrm{kg} \mathrm{DM}$} & \multicolumn{2}{c|}{$\mathrm{g} / \mathrm{d}$} \\
\hline & Protein & Fat & Starch & NSP & $\begin{array}{c}\text { Total } \\
\text { fibre }\end{array}$ & $\begin{array}{c}\text { Total } \\
\text { fibre }\end{array}$ & $\begin{array}{c}\text { Total } \\
\text { ferm. } \\
\text { fibre }\end{array}$ \\
\hline $\mathrm{CH}_{4}, \mathrm{~L} / \mathrm{d}$ & -0.42 & -0.23 & -0.32 & 0.71 & 0.63 & 0.75 & 0.86 \\
\hline $\mathrm{CO}_{2}, \mathrm{~L} / \mathrm{d}$ & -0.61 & -0.47 & 0.18 & 0.33 & 0.34 & 0.65 & 0.62 \\
\hline & & & & & & & \\
\hline
\end{tabular}

Table 3. Pearson correlations of chemical compositions (g/kg DM, g/d) and excretion of methane and carbon dioxide $(\mathrm{L} / \mathrm{d})$ of 140 diets/treatments. $\mathrm{P}<0.05$.

NSP, non starch polysaccharides. Total fibre, calculated as the residual fraction after subtraction of the analysed content of sugars, starch, crude protein, crude fat and ash from the dry matter content. Total fermentable fibre, the amount being fermented in the hind-gut of the intestine. 


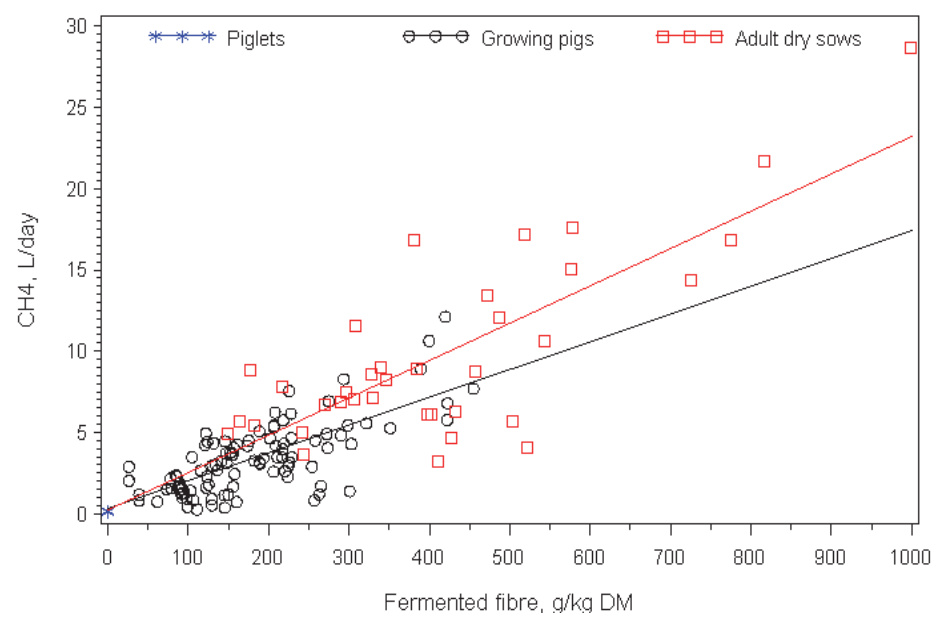

Fig. 3. Plot of $\mathrm{CH}_{4}$ excretion (L/day) against total fermented fibre (g/kg Dry Matter intake) on the total dataset $(n=140)$.

There is a strong relationship between $\mathrm{CO}_{2}$ production and $\mathrm{DM}$ intake $(\mathrm{r}=0.87)$ and between $\mathrm{CO}_{2}$ production and body weight $(\mathrm{r}=0.83)$. This is a reflection of the growth of the animals as the metabolic pathways involved in maintenance and growth require energy, which will lead to $\mathrm{CO}_{2}$ production (Figure 4, black circles from growing pigs at maintenance + retention). In a comprehensive review of the metabolic studies from the Oscar-Kellner Institute it was shown that increasing the daily weight gain of animals results in an overall lower $\mathrm{CO}_{2}$ emission (Jentsch et al. 2009) as higher daily weight gain results in relatively less amount of energy required for maintenance. From Figure 4 it can also be seen that the $\mathrm{CO}_{2}$ production from the adult sows (red squares) up to a DM intake of approximately 3.5 $\mathrm{kg}$ /day is higher because the sows at the low feed intake are fed at maintenance where energy intake is equivalent to the amount of energy oxidised.

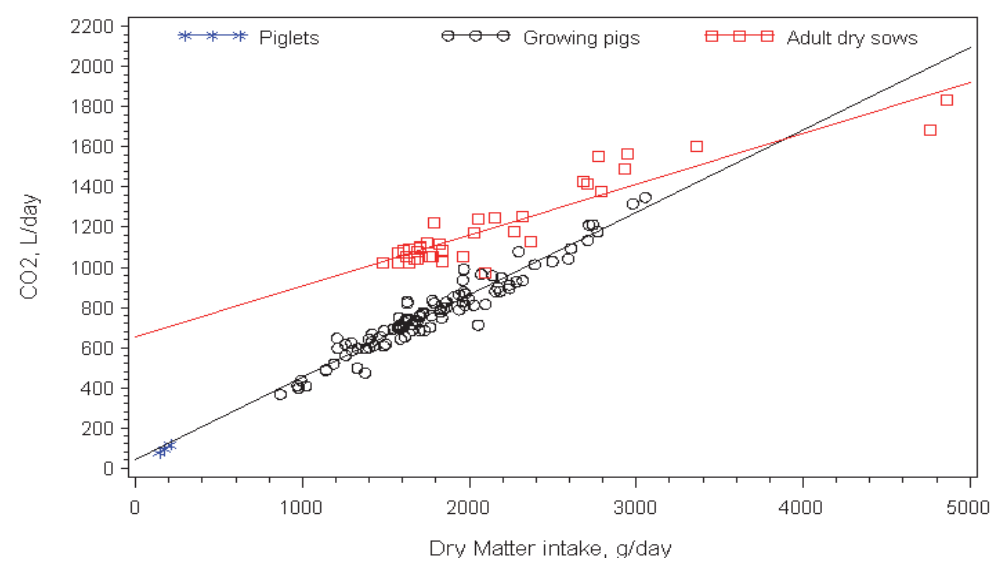

Fig. 4. Plot of $\mathrm{CO}_{2}$ excretion (L/day) against total Dry Matter intake (g/day) on the total dataset $(n=140)$. 


\subsection{Diurnal variation in methane and carbon dioxide}

Table 2 shows the average excretion of $\mathrm{CH}_{4}$ and $\mathrm{CO}_{2}$ of the three classes of pigs. However, close inspection of the results revealed large diurnal variation depending on feeding and physical activity, and the digestion and fermentation in the intestine. Figure 5 show an example of diurnal variation in a growing pig fed a diet containing sugar beet pulp (a type of fibre easily fermented). The variation in $\mathrm{CO}_{2}$ is mainly a reflection of feeding a meal and the subsequent activity (Le Goff et. al. 2002; Schrama et al. 1998 and review by Pedersen et al. 2008). The animals here are fed twice daily at 08.00 and $15.00 \mathrm{~h}$. The lowest $\mathrm{CO}_{2}$ concentration is found during night-time from around 20.00 in the evening to 07.00 the next morning. This is the period with the lowest heat production during the day and can be defined as basal metabolic rate or maintenance. The sudden increase in $\mathrm{CH}_{4}$ concentration shown occasionally is related to the activity where the animals stand up and release some intestinal gas (flatulence).

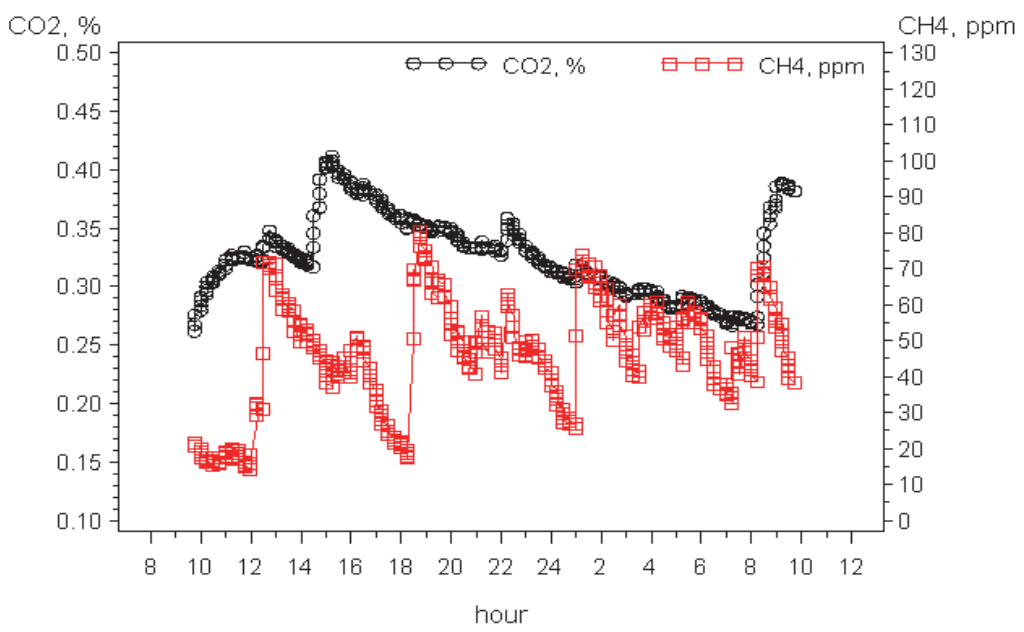

Fig. 5. Typical diurnal variation in concentration of carbon dioxide $\left(\mathrm{CO}_{2}\right)$ and methane $\left(\mathrm{CH}_{4}\right)$ in the outgoing air from the respiration chamber with a growing pig fed a diet containing sugar beet pulp. The gas from the respiration chamber is measured every 4 minutes.

\subsection{Influence of dietary fat on enteric methane emission}

Dietary fat can potentially influence the $\mathrm{CH}_{4}$ production, as have been shown in ruminants (Beaucemin \& McBurn, 2006), due to biohydrogenation of unsaturated fatty acids and enhanced propionate production. Fat sources with medium chain fatty acids i.e. coconut oil and palm oil is also shown to depress $\mathrm{CH}_{4}$ production in ruminants (Machmüller et al, 2003). In two of our studies, growing pigs have been fed increasing amount of either rapeseed oil or fish oil (Jørgensen et al. 1996; Jørgensen unpublished) and one study with adult sows using animal fat (Theil et al. 2004). The concentration of dietary fat varied from 3 to $21 \%$ but had only a small and insignificant influence on the $\mathrm{CH}_{4}$ production. However, neither of these experiments was specifically designed to investigate the effect on $\mathrm{CH}_{4}$ production and all diets had a relatively low level of dietary fibre (12 - 18\% dietary fibre), which is the main substrate for fermentation. Similar observation was done by Noblet \& Shi 
(1994) who did not find evidence of a digestive interaction between dietary fat and fibre. Pigs, as non-ruminants, digest the majority of various fat sources up to $90 \%$, (Jørgensen and Fernández, 2000; Jørgensen et al. 2003) and when feeding fish oil or coconut oil, as much as $94 \%$ of the fat is digested at the terminal ileum (Jørgensen et al. 1996; 2000). It is therefore only limited amount of the dietary fatty acids that reach the large intestine with a potential for reducing the $\mathrm{CH}_{4}$ production.

\subsection{Influence of environmental temperature on enteric methane emission}

In ruminants it is generally assumed that $\mathrm{CH}_{4}$ production decreases with increasing passage rates associated with cold adaptation (McAllister et al. 1996). In order to evaluate if low ambient temperature decreases $\mathrm{CH}_{4}$ production in pigs, results from three experiments where ambient temperature have varied in the range $12-29^{\circ} \mathrm{C}$ were evaluated (Theil et al. 2001). A tendency was seen for a reduced $\mathrm{CH}_{4}$ production at the low temperature independent of whether $\mathrm{CH}_{4}$ was corrected for differences in feed intake or not.

\subsection{Influence of body weight on methane emission}

The pigs' gastrointestinal tract develops with age (and weight) towards increased capacity and ability to ferment the dietary fibre fraction of the diet. This is illustrated in Figure 6 for growing pigs.

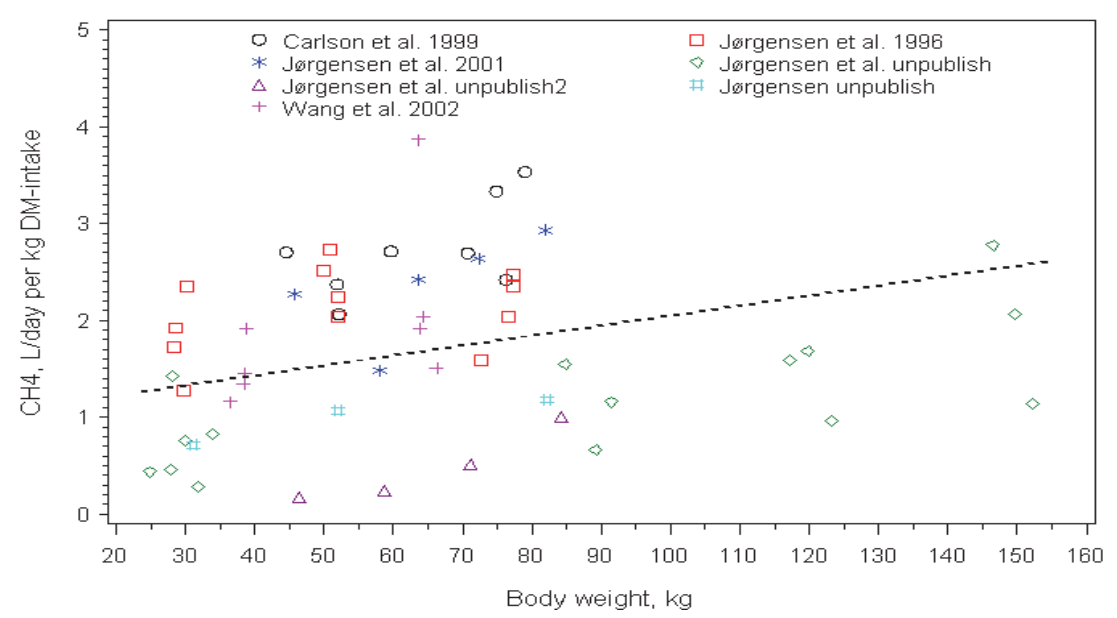

Fig. 6. Influence of body weight on fermentation/excretion of $\mathrm{CH}_{4}$ when the excretion is corrected for feed intake (L/day per kg Dry Matter intake).

The results are from experiments where equal types of diet are fed through several periods (i.e. Latin square design). The results show some variation from period to period, but the general trend is increasing $\mathrm{CH}_{4}$ emission in response to increasing body weight. However, as the pigs grow, daily feed intake increases as well and in order to test the influence of only body weight, the $\mathrm{CH}_{4}$ production is corrected for differences in feed intake (DM intake) as shown in the Figure. Even with this correction there is a significant effect of body weight on $\mathrm{CH}_{4}$ production, and the derived equations are shown below: 


$$
\mathrm{CH}_{4}, \mathrm{~L} / \text { day per } \mathrm{kg} \text { DM intake }=1.01+0.0107 \times \mathrm{BW}, \mathrm{kg}, \mathrm{n}=55, \mathrm{R}^{2}=0.71
$$

The effect of body weight was minor, however, significant in agreement with the studies by Christensen \& Thorbek (1987) and Noblet \& Shi (1994). However, Kirchgessner and coworkers concluded in a summary of several of their experiments that methanogenesis in pigs is fairly independent of live weight if feeding condition is kept constant.

\subsection{Comparison between growing pigs and adults sows fed similar types of fiber}

A comparison of the ability of growing pigs and sows to digest and utilise various fibre rich feedstuffs is shown in Figure 7. The data in Figure 7 is limited to experiments where the animals are fed the same type of fibre. The results demonstrate that both growing pigs and sows produce equal amounts of $\mathrm{CH}_{4}$ per $\mathrm{g}$ fermented fibre. However, the sows had a much greater fermentative capacity, i.e. they can ferment a much larger amount of fibre per day.

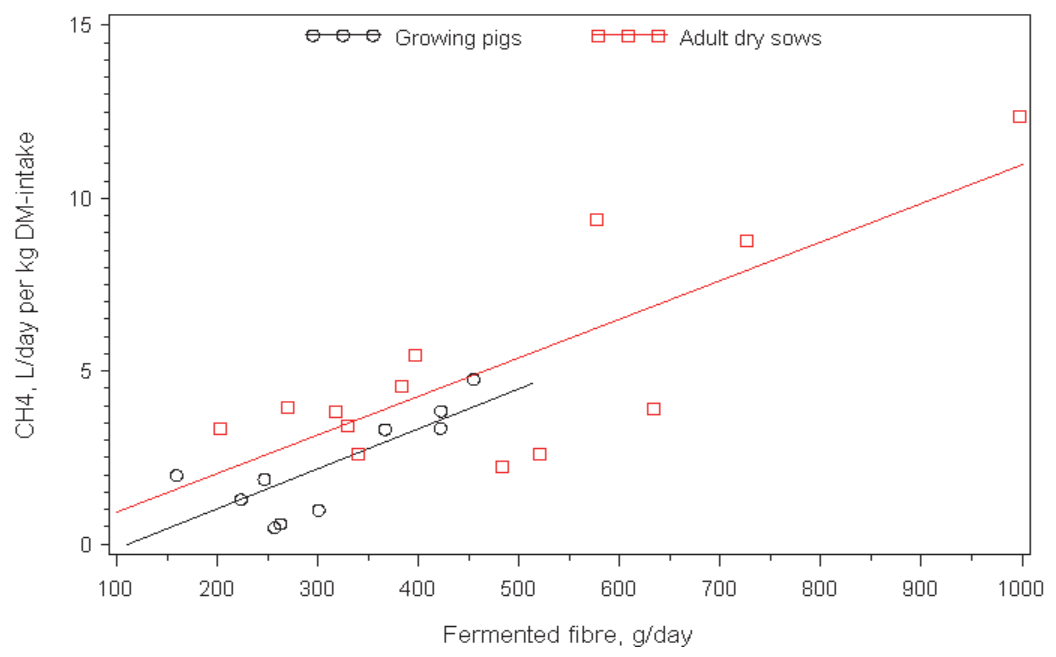

Fig. 7. Influence of body weight (growing pigs $v$ s adult sows) on fermentation/excretion of $\mathrm{CH}_{4}$ in experiments where the animals are fed equal types of fibers and the excretion is corrected for feed intake (L/day per kg Dry Matter intake).

In the actual experiments neither the sows nor the growing pigs were able to consume more of the most voluminous fibre feedstuffs. No significant difference between the slopes from the two classes of animals was found. Therefore, emission of methane in pigs per unit of feed ingested can be expressed as:

$$
\begin{array}{r}
\mathrm{CH}_{4}, \mathrm{~L} / \text { day per } \mathrm{kg} \text { DM intake }=-7.57+ \\
0.0112 \times \text { Fermented Fibre, } \\
\mathrm{g} / \text { day, } \mathrm{n}=23, \mathrm{R}^{2}=0.71
\end{array}
$$

A reduced feed intake allow more time for fermentation and as a result more enteric $\mathrm{CH}_{4}$ is produced as found by Christensen \& Thorbek (1987) in a study with reduced feed intake to growing pigs. This could also be the case when adult sows in the dry period and during pregnancy are fed relative restricted (2-2.5 $\mathrm{kg}$ DM per day) in order not to gain excessive 
weight because this may cause health problems around farrowing and lactation. In the last 3-4 weeks of the pregnancy period, the feeding level is in general increased to $3.5 \mathrm{~kg}$ DM per day. This was tested in three of the experiments with sows; however there was a nonsignificant decrease in $\mathrm{CH}_{4}$ emission expressed per kg dry matter intake.

\subsection{Comparison between growing pigs and adult sows-data from the whole database}

When the whole database was used to compare the $\mathrm{CH}_{4}$ emission in growing pigs and adult sows the results are shown in Figure 8.

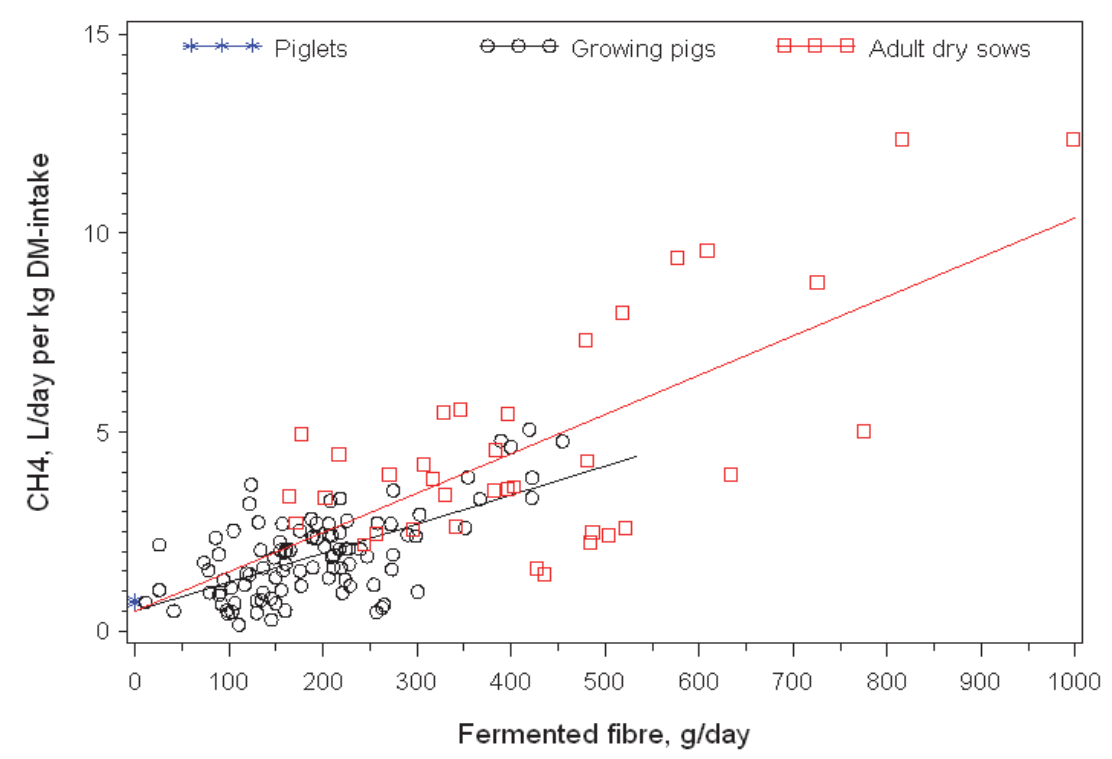

Fig. 8. Influence of body weight (growing pigs $v$ s adult sows) on fermentation/excretion of $\mathrm{CH}_{4}$ when plotting the whole dataset $(n=140)$ the excretion is corrected for feed intake (L/day per kg Dry Matter intake).

The results show large variation in the fermentability of the different fibres depending on fibre type but it was also found that some animals had low $\mathrm{CH}_{4}$ production independent of amount and type of fibre. When comparing the contribution of the different fibre rich feedstuffs to the $\mathrm{CH}_{4}$ emission it should be kept in mind that the lower energy digestibility in fibre rich feedstuffs compared to concentrated feeds implies that the pigs must consume a larger quantity of feed to obtain the same production. When the $\mathrm{CH}_{4}$ production was expressed as either L/day or L/day per $\mathrm{kg}$ DM intake, there was no significant difference between growing pigs and adult sows:

$$
\begin{array}{r}
\mathrm{CH}_{4}, \mathrm{~L} / \text { day }=0.440+0.0206 \times \text { Fermented Fibre, } \\
\mathrm{g} / \text { day }, \mathrm{n}=137, \mathrm{R}^{2}=0.74
\end{array}
$$




$$
\begin{aligned}
& \mathrm{CH}_{4} \text {, L / day per } \mathrm{kg} \text { DM intake }=0.626+0.00894 \times \text { Fermented Fibre, } \\
& \mathrm{g} / \text { day, } \mathrm{n}=137, \mathrm{R}^{2}=0.64
\end{aligned}
$$

However, when the $\mathrm{CH}_{4}$ emission was expressed relative to either GE or DE the slopes for growing pigs and sows were significant different and expressed as:

$$
\begin{array}{r}
\mathrm{CH}_{4} \text { - energy, \% GE }=0.0628+0.00277 \text { (growing pigs) } \times \text { Fermented Fibre, g } / \mathrm{kg} \mathrm{DM} \\
\mathrm{CH}_{4} \text {-energy, \% GE }=0.0628+0.00488(\text { adult sows) } \times \text { Fermented Fibre, g } / \mathrm{kg} \mathrm{DM} \\
\mathrm{n}=137, \mathrm{R}^{2}=0.72 \\
\mathrm{CH}_{4} \text { - energy, \% DE }=0.0838+0.00376 \text { (growing pigs) } \times \text { Fermented Fibre, } \mathrm{g} / \mathrm{kg} \mathrm{DM} \\
\mathrm{CH}_{4} \text { - energy, \% DE }=0.0838+0.00606 \text { (adult sows) } \times \text { Fermented Fibre, } \mathrm{g} / \mathrm{kg} \mathrm{DM}
\end{array}
$$

On average, energy from $\mathrm{CH}_{4}$ relative to $\mathrm{DE}$ amounted to $0.68 \%$ (Table 2). However, energy loss of $\mathrm{CH}_{4}$ in adult sows was approximately three times higher $(1.31 \%$ of DE) than in growing pigs $(0.47 \%$ of $\mathrm{DE})$. The reason for the higher loss of $\mathrm{CH}_{4}$ in proportion of DE per $\mathrm{g}$ of fermented fibre in sows than in growing pigs is, as discussed by Jørgensen (2007), the sow's relatively greater capacity for fermentation. A factor of importance is also that non-pregnant sows were fed relatively less relative to the body size. The values estimated in current compilation are comparable to results obtained by Schrama et al. (1998) for growing pigs and Kirchgessner et al. (1991) and Le Goff et al. (2002) for adult sows or used by Vermorel et al. (2008) in an assessment of enteric methane emission by farm animals in France. As indicated in Table 2, the $\mathrm{CH}_{4}$ production in sows could be as high as $3.25 \%$ of DE.

The average $\mathrm{CH}_{4}$ production by growing pigs was estimated $0.39 \%$ of GE or $0.47 \%$ of DE, which is lower than the value for all classes of pigs ( $0.6 \%$ of GE) assumed in the report on emission of greenhouse gases from Danish agriculture (Mikkelsen et al., 2006; 2011). If the value of $\mathrm{CH}_{4}$-energy $(1.0 \%$ of $\mathrm{GE}$ or $1.3 \%$ of $\mathrm{DE})$ is representative for diets for sows (lactating and non-lactating), then the value in the latter report is underestimated for this class of pigs.

\subsection{Case study - methane emission when feeding low and high fiber diets to growing pigs and adult sows}

In Table 4 are shown examples of the typical variations in diet composition that may influence the $\mathrm{CH}_{4}$ emission from pigs (Sørensen and Fernandez, 2003). All the diets were formulated to satisfy the nutritive recommendations and they resemble diets used in practice.

Over the last two decades diets have been formulated closer to pigs' requirement with regard to amino acid composition to reduce N-pollution to the environment. This is illustrated with diet no. 5 and 6 (Table 4), where diet no. 6 is supplemented with free amino acids. Both diets having the same growth potential but diet no. 6 had reduced protein content and a reduced content of especially soybean meal. Because less fibre is fermented a lower $\mathrm{CH}_{4}$ production can be expected. Sugar beet pulp was used to increase the concentration of dietary fibre in diet 7 , which resulted in higher fermentation of fibre and, consequently, emission of $\mathrm{CH}_{4}$ that was $60 \%$ higher compared to diet 6 at the same daily gain. 


\begin{tabular}{|c|c|c|c|c|c|c|}
\hline \multirow{2}{*}{$\begin{array}{lr} & \text { Animal } \\
\text { Diet }^{1} & \\
\end{array}$} & \multicolumn{3}{|c|}{ Growing pigs } & \multicolumn{3}{|c|}{ Adult sows } \\
\hline & 5 & 6 & 7 & 9 & 11 & 12 \\
\hline \multicolumn{7}{|l|}{ Composition, \% } \\
\hline Wheat & 33.3 & 40.1 & 22.0 & 45.2 & - & 40.7 \\
\hline Barley & 25.1 & 33.9 & 30.4 & 38.5 & 81.2 & 4.6 \\
\hline Sunflower cake & - & - & - & 5.7 & - & - \\
\hline Rapeseed cake & - & - & - & 3.0 & - & - \\
\hline Barley straw & - & - & - & 5.0 & - & - \\
\hline Soybean meal & 15.4 & 10.0 & 19.5 & 0.5 & 3.7 & - \\
\hline Peas & 11.6 & 4.3 & - & - & - & - \\
\hline Sweet lupine & 10. & 6.6 & 10.9 & - & 0.5 & 10.0 \\
\hline Sugar beet pulp & 2.0 & 2.0 & 15.0 & - & 12.5 & 42.8 \\
\hline DL-Methionine 40 & 0.14 & 0.20 & 0.13 & - & 0.05 & 0.13 \\
\hline L-Threonine 50 & - & 0.30 & - & - & 0.05 & 0.19 \\
\hline L-Lysine 50 & - & 0.70 & - & - & - & - \\
\hline Min.+Vit. Mix & 2.46 & 1.90 & 2.07 & 2.10 & 2.00 & 1.48 \\
\hline \multicolumn{7}{|l|}{ Chemical composition } \\
\hline Protein. \% in DM & 23.3 & 20.0 & 23.2 & 14.6 & 13.0 & 15.1 \\
\hline Dietary fibre, \% DM & 22.5 & 21.0 & 29.8 & 22.6 & 27.9 & 41.5 \\
\hline DM-intake. $\mathrm{kg} / \mathrm{d}$ & 1.68 & 1.70 & 1.80 & 1.85 & 1.83 & 1.81 \\
\hline DC energy, $\%$ & 83 & 82 & 78 & 82 & 83 & 84 \\
\hline Ferm fibre, $\mathrm{g} / \mathrm{kg}$ DM & 139 & 123 & 194 & 106 & 180 & 335 \\
\hline Expected $\mathrm{CH}_{4}, \mathrm{~L} / \mathrm{d}^{2}$ & 5.5 & 5.1 & 8.0 & 4.9 & 7.6 & 13.3 \\
\hline $\mathrm{CH}_{4}$-energy, \% GE 3 & 0.45 & 0.40 & 0.60 & 0.58 & 0.94 & 1.70 \\
\hline $\mathrm{CH}_{4}$-energy, \% DE 4 & 0.61 & 0.55 & 0.81 & 0.73 & 1.17 & 2.11 \\
\hline
\end{tabular}

1 The diet number refers to the diet in the paper of Sørensen \& Fernandéz (2003). DC, digestibility coefficient; GE, gross energy; DE, digestible energy.

2 Estimated using equation no 4.

${ }^{3}$ Estimated using equation no 6.

4 Estimated using equation no 7.

Table 4. Examples on trend in diets for growing pigs and dry sows *data from Sørensen \& Fernandéz (2003).

Restricted feeding is generally used for dry and gestating sows to avoid overweight, which can lead to farrowing and locomotion problems. An undesired effect of that are animal welfare problems such as stereotypic behaviour, which, however, can be reduced by feeding high fibre diets. The consequences of increasing the fibre content are illustrated by diet no. 11 and 12 relative to diet 9 . Diet no. 9 contains fibre with relative high content of insoluble fibre from barley straw, which illustrates a situation where the sows eat some of the bedding material, which is common. Insoluble fibre is more resistant to fermentation and subsequently the amount of fermented fibre is the lowest of the three diets and the calculated $\mathrm{CH}_{4}$ emission is low too. In diets no. 11 and no. 12, the amount of fermentable 
fibre is increased by adding sugar beet pulp, which resulted in almost a tripling of the $\mathrm{CH}_{4}$ emission when comparing diet no. 12 with diet 9.

Formulating diets closer to pigs' requirement and using a variety of feedstuffs it is thus possibly to reduce the $\mathrm{CH}_{4}$ emission without compromising the animal performance. In ruminants there is in a meta-analysis shown strong indication that dietary tannins is related to $\mathrm{CH}_{4}$ emission (Jayanegara et al. 2011), however, it remains to be shown if dietary tannins have any influence on the enteric $\mathrm{CH}_{4}$ emission from pigs.

\section{Implications on alterations in pig feeding}

The enteric $\mathrm{CH}_{4}$ production may be reduced by altering the feed composition of the diet. Formulation of diets rich in fat, starch and protein and low in fiber will be optimal if the major interest is to reduce the methane emission. The most prominent effect will be to reduce the dietary fiber content. However, feeding pigs is a complex issue, and feed composition and feeding strategies should satisfy a number of various aspects.

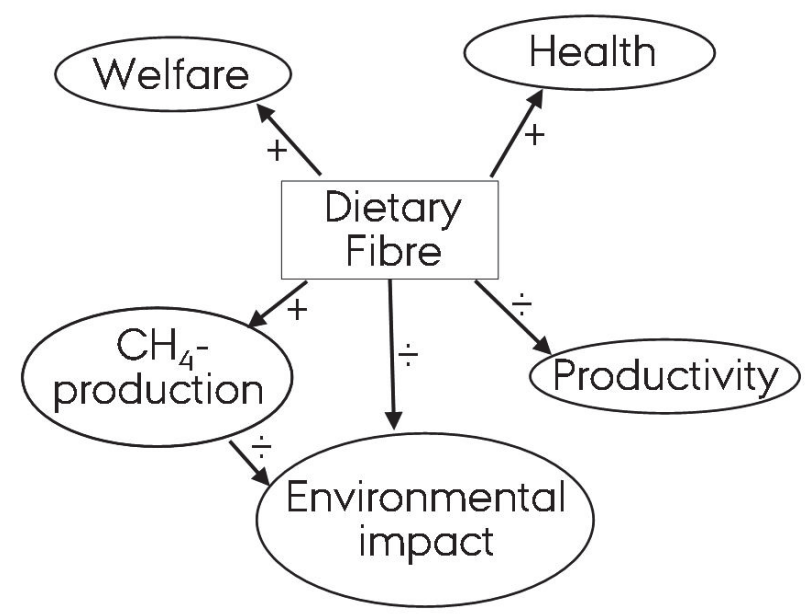

Fig. 9. Relationship between dietary fibre intake (the main source of enteric methane emission) and traits related to the environment and pig production. $(\div$ indicate negative effect and + indicate positive effect).

If low fiber diets are generally applied in pig feeds, it will improve their productivity, and the pollution load caused by excreted nutrients will be reduced. However, concomitantly low fiber diets will be detrimental for the animal health, fiber is important for the health of the intestine and consumption of fiber prevents e.g. gastric ulcers. Moreover, dietary fiber improve the welfare of e.g. sows by reducing gastric emptying rate (Jørgensen et al., 2010), hunger and stereotypic behaviour when they are fed restrictedly throughout gestation (Figure 9).

\section{Conclusion}

The main dietary contributor to the $\mathrm{CH}_{4}$ enteric emission at all live weight of pigs is the dietary concentration of fibre, whereas neither dietary fat nor protein had any significant 
impact on the $\mathrm{CH}_{4}$ emission. The lack of effect of dietary fat on the $\mathrm{CH}_{4}$ emission is possibly due to a very high digestibility of the fat in the small intestine.

Production of $\mathrm{CH}_{4}$ by piglets is low and amounts to only $0.13 \mathrm{~L} /$ day or $0.1 \%$ of GE. For growing pigs' feed, a low fibre diet or a standard diet, the $\mathrm{CH}_{4}$ emission can be estimated from 0.2 to $0.5 \%$ of GE corresponding to $3.4 \mathrm{~L} /$ day for an average slaughter pig and thus lower than the standard $0.6 \%$ of GE recommended by ICPP (2006) or used by Mikkelsen et al. (2011). When feeding diets with higher fibre content, the $\mathrm{CH}_{4}$ emission depends on type and might contribute up to $1 \%$ of GE. Dry and gestating sows fed at maintenance have a $\mathrm{CH}_{4}$ emission varying from 0.6 to $2.7 \%$ of GE depending on feeding level and fibre type, whereas the $\mathrm{CH}_{4}$ emission of lactating sows is estimated to be approximately $0.6 \%$ of GE. In all the experiments the $\mathrm{CH}_{4}$ emission of sows has been found to exceed the standard $0.6 \%$ of GE recommended by the ICPP.

The Danish pig production is rather intensive meaning that the standard pig feed contain less dietary fermentable fibre than when pigs are raised under more extensive production e.g. countries in Asia. This implies that the methane emission from the global pig production could be higher than the average values found under Danish conditions.

\section{References}

Beauchemin, K.A. \& McGinn, S.M. 2006. Methane emission from beef cattle: Effects of fumaric acid, essential oil, and canola oil. J. Anim. Sci. 84:1489-1496.

Christensen, K. \& Thorbek, G. 1987. Methane excretion in the growing pig. Br. J. Nutr. 57:355-361.

FAOSTAT. 2009. FAO Statistical Database, Food and Agriculture Organization of the United Nations, Rome, Italy. Accessed 22.06.2011 at http://faostat.fao.org/site/573/ default.aspx.

Fernández, J.A., Jørgensen, H. \& Just, A. 1986. Comparative digestibility experiments with growing pigs and adult sows. Anim. Prod. 43:127-132.

IPCC. 2006. Guidelines for National Greenhouse Gas Inventories. Agriculture, forestry and other land use; Emission from livestock and manure management, volume 4, Chap. 10, 87pp.

Jakobsen, K., Theil, P.K. \& Jørgensen, H. 2005. Methodological considerations as to quantify nutrients and energy metabolism in lactating sows. J. Anim. Feed Sci. 14:31-47.

Jayanegara, F., Leiber, F. \& Kreuzer, M. 2011. Meta-analysis of the relationship between dietary tannin level and methane formation in ruminants from in vivo and in vitro experiments. J. Anim. Physiol- Anim. Nutr. In press doi:10.1111/j.14390396.2011.01172.x.

Jensen, B.B. \& Jørgensen, H. 1994. Effect of dietary fiber on microbial activity and microbial gas production in various regions of the gastrointestinal tract of pigs. Appl. environ. Microbiol. 60:1897-1904.

Jensen, B.B. 1996. Methanogenesis in monogastric animals. Environ. Monit. Assess. 42:99-112.

Jentsch, W., Schweigel, M., Weissbach, H.S., Pitroff, W. \& Derno, M. 2007. Methane production in cattle calculated by the nutrient composition of the diet. Arch. Anim. Nutr. 61:10-19.

Jentsch, W., Piatkowski, B. \& Derno, M. 2009. Relationship between carbon dioxide production and performance in cattle and pigs. Arch. Tierzucht. 52:485-496.

Johnson, K.A. and Johnson, D.E. 1995. Methane emissions from cattle. J. Anim. Sci. 73:24832492. 
Just, A., Jørgensen, H., Fernández, J.A., Bech-Andersen, S. \& Enggaard Hansen, N. 1983 Forskellige foderstoffers kemiske sammensætning, fordøjelighed, energi- og proteinværdi til svin. 556. Report from the National Institute of Animal Science, Denmark, 99 pp.

Jørgensen, H. 1997. Energy utilization of diets with different sources of dietary fibre in growing pigs. In: K. J. McCracken, E. F. Unsworth, and A. R. G. Wylie (Eds.) Energy Metabolism of Farm Animals. pp. 367-370. CAB International, University Press, Cambridge.

Jørgensen, H. 2001. Energimålinger ved hjælp af respirationskamre. JordbrugsForskning 5:6-7.

Jørgensen, H. 2007. Methane emission by growing pigs and adult sows as influenced by fermentation. Livest. Sci. 109:216-219.

Jørgensen, H. \& Fernández, J.A. 2000. Chemical composition and energy value of different fat sources for growing pigs. Acta Agric. Scand. Sect. A-Anim. Sci. 50:129-136.

Jørgensen, H., Jensen, S.K. \& Eggum, B.O. 1996. The influence of rapeseed oil on digestibility, energy metabolism and tissue fatty acid composition in pigs. Acta Agric. Scand., Sect. A, Anim. Sci. 46:65-75.

Jørgensen, H., Zhao, X.Q. \& Eggum, B.O. 1996. The influence of dietary fibre and environmental temperature on the development of the gastrointestinal tract, digestibility, degree of fermentation in the hind-gut and energy metabolism in pigs. Br. J. Nutr. 75:365-378.

Jørgensen, H., Larsen, T., Zhao, Z.Q. \& Eggum, B.O. 1997. The energy value of short-chain fatty acids infused into the caecum of pigs. Br. J. Nutr. 77:745-756.

Jørgensen, H., Gabert, M.V., Hedemann, M.S. \& Jensen, S.K. 2000. Digestion of fat does not differ in growing pigs fed diets containing fish oil, rapeseed oil or coconut oil. J. Nutr. 130:852-857.

Jørgensen, H., Bach Knudsen, K.E. \& Theil, P.K. 2001. Effect of dietary fibre on energy metabolism of growing pigs and pregnant sows. In: A. Chwalibog and K. Jakobsen (Eds.) Energy Metabolism in Animals. pp. 105-108. Wageningen Pers, Wageningen.

Jørgensen, H., Fernández, J.A. Krogh Jensen, S. \& Danielsen, V. 2003. Effect of fat sources and rapeseed lecithin on fat digestibility and utilization in young pigs. Pages 12541256 in Proceedings 11th International Rapeseed Congree. H. Sørensen ed. Samfundslitteratur Grafik, Gylling.

Jørgensen, H., Serena, A., Hedemann, M.S. \& Bach Knudsen, K.E. 2007. The fermentative capacity of growing pigs and adult sows fed diets with contrasting type and level of dietary fibre. Livest. Sci. 109:111-114.

Jørgensen, H., Strathe, A., Theil, P.K. \& Bach Knudsen, K.E. 2010. Evaluation of a simple non-invasive $13 \mathrm{C}$ breath test to evaluate diet effects on gastric emptying in pigs. Livest. Sci. 133:64-66.

Kirchgessner, M., Kreuzer, M., Müller, H.L. \& Windisch, W. 1991. Release of methane and of carbon dioxide by the pig. Agribiol. Res. 44:103-113.

Le Goff, G., Le Groumellec, L., van Milgen, J., Dubois, S. \& Noblet, J. 2002. Digestibility and metabolic utilisation of dietary energy in adult sows: influence of addition and origin of dietary fibre. Br. J. Nutr. 87:325-335.

Lekule, F.P., Jørgensen, H., Fernández, J.A. \& just, A. 1990. Nutritive value of some tropical feedstuffs for pigs. Chemical composition, digestibility and metabolizable energy content. Anim. Feed Sci. Technol. 28:91-101.

McAllister, T.A., Okine, E.K., Mathison, G.W. \& Cheng, K.-J. 1996. Dietary, environmental and microbiological aspects of methane production in ruminants. Can. J. Anim. Sci. 76:231-243. 
Machmüller, A., Soliva, C.R. \& Kreuzer, M. 2003. Methane-suppressing effect of myristic acid in sheep as affected by dietary calcium and forage proportion. Br J. Nutr. 90:529-540.

Mikkelsen, M.H., Gyldenkærne, S., Poulsen, H.D., Olesen, J.E. \& Sommer, S.G. 2006. Emission of ammonia, nitrous and methane from Danish agriculture 1985 - 2002. Methodology and estimates. Research notes from NERI, no. 231. National Enviromental Research Institute. Ministry of the Environment, Denmark. 88 pp.

Mikkelsen, M.H., Albrektsen, R. \& Gyldenkærne, S. 2011. Danish emission inventories for agriculture. Inventories 1985 - 2009. National Research Institute, Aarhus University. - NERI Technical Report No. 810. 136 pp.

Miller, T.L. \& Wolin, M.J. 1974. Fermentations by saccharolytic intestinal bacteria. Am J. Clin. Nutr. 32:164-172.

Noblet, J \& Shi, X.S. 1994. Effect of body weight on digestive utilization of energy and nutrients of ingredients and diets in pigs. Livest. Prod. Sci. 37:323-338.

Olesen, C.S. \& Jørgensen, H. 2001. Effect of dietary fibre on digestibility and energy metabolism in pregnant sows. Acta Agric. Scand. Sect. A-Animal Sci. 51:200-207.

Pedersen, S., Blanes-Vidal, V., Jørgensen, H., Chwalibog, A., Haeussermann, A., Heetkamp, M.J.W. \& Aarmink, A.J.A. 2008. Carbon dioxide production in animal houses: A literature review. Agric. Eng. Int. GICR Ejournal X:1-19.

Schrama, J.W., Bosch, M.W., Verstegen, M.V.A., Vorselaars, A.H.P.M., Haaksma, J. \& Heetkamp, M.J.W. 1998. The energetic value of nonstarch polysaccharides in relation to physical activity in group-housed, growing pigs. J. Anim. Sci. 76:3016-3023.

Serena, A., Jørgensen, H. \& Bach Knudsen, K.E. 2007. Nutritional value of co-products from vegetable food industry. Pages 473-491 in Paradigms in pig science. J. Wiseman, M. A. Varley, S. McOrist, and B. Kemp eds. Nottingham University Press, Nottingham.

Serena, A., Jørgensen, H. \& Bach Knudsen, K.E. 2008. Digestion of carbohydrates and utilization of energy in sows fed diets with contrasting levels and physicochemical properties of dietary fiber. J. Anim Sci. 86:2208-2216.

Serena, A., Jørgensen, H. \& Bach Knudsen, K.E. 2009. Absorption of carbohydrate-derived nutrients in sows as influenced by types and contents of dietary fiber. J. Anim Sci. 87:136-147.

Stryer, L. 1988. Biochemistry. 1089 pp. W.H. Freeman and Company. New York.

Sørensen, P. \& Fernández, J.A. 2003. Dietary effects on the composition of pig slurry and on the plant utilization of pig slurry nitrogen. J. Agric. Sci. 140:343-355.

Theil, P.K., Jørgensen, H. \& Jakobsen, K. 2002. Energy and protein metabolism in pregnant sows fed two levels of dietary protein. J. Anim. Physiol. Anim. Nutr. 86:399-413.

Theil, P.K., Jørgensen, H. \& Jakobsen, K. 2004. Energy and protein metabolism in lactating sows fed two levels of dietary fat. Livest. Prod. Sci. 89:265-276.

Theil, P.K., Kristensen, N.B., Jørgensen, H., Labouriau, R. \& Jakobsen, K. 2007. Milk intake and carbon dioxide production of piglets determined with the doubly labelled water technique. Animal 1:881-888.

Vermorel, M., Jouany, J.-P., Eugéne, M., Sauvant, D., Noblet, J. \& Dourmad, J.-Y. 2008. Evaluation quantitative des émissions de méthane entérique par les animaux d'élevage en 2007 en France. INRA Prod. Anim. 21:403-418.

Wang, J.F., Zhu, Y.H., Li, D.F., Jørgensen, H. \& Jensen, B.B. 2004. The influence of different fibre and starch types on nutrient balance and energy metabolism in growing pigs. Asian-Australian J. Anim. Sci. 17:263-270. 


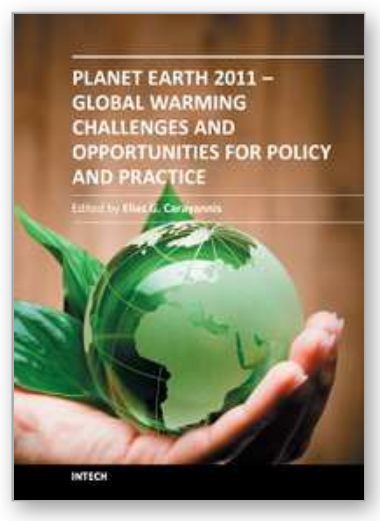

\section{Planet Earth 2011 - Global Warming Challenges and Opportunities for Policy and Practice}

Edited by Prof. Elias Carayannis

ISBN 978-953-307-733-8

Hard cover, 646 pages

Publisher InTech

Published online 30, September, 2011

Published in print edition September, 2011

The failure of the UN climate change summit in Copenhagen in December 2009 to effectively reach a global agreement on emission reduction targets, led many within the developing world to view this as a reversal of the Kyoto Protocol and an attempt by the developed nations to shirk out of their responsibility for climate change. The issue of global warming has been at the top of the political agenda for a number of years and has become even more pressing with the rapid industrialization taking place in China and India. This book looks at the effects of climate change throughout different regions of the world and discusses to what extent cleantech and environmental initiatives such as the destruction of fluorinated greenhouse gases, biofuels, and the role of plant breeding and biotechnology. The book concludes with an insight into the socio-religious impact that global warming has, citing Christianity and Islam.

\section{How to reference}

In order to correctly reference this scholarly work, feel free to copy and paste the following:

Henry Jørgensen, Peter K. Theil and Knud Erik Bach Knudsen (2011). Enteric Methane Emission from Pigs, Planet Earth 2011 - Global Warming Challenges and Opportunities for Policy and Practice, Prof. Elias Carayannis (Ed.), ISBN: 978-953-307-733-8, InTech, Available from: http://www.intechopen.com/books/planetearth-2011-global-warming-challenges-and-opportunities-for-policy-and-practice/enteric-methane-emissionfrom-pigs

\section{INTECH}

open science | open minds

\author{
InTech Europe \\ University Campus STeP Ri \\ Slavka Krautzeka 83/A \\ 51000 Rijeka, Croatia \\ Phone: +385 (51) 770447 \\ Fax: +385 (51) 686166 \\ www.intechopen.com
}

\author{
InTech China \\ Unit 405, Office Block, Hotel Equatorial Shanghai \\ No.65, Yan An Road (West), Shanghai, 200040, China \\ 中国上海市延安西路65号上海国际贵都大饭店办公楼 405 单元 \\ Phone: +86-21-62489820 \\ Fax: $+86-21-62489821$
}


(C) 2011 The Author(s). Licensee IntechOpen. This chapter is distributed under the terms of the Creative Commons Attribution-NonCommercialShareAlike-3.0 License, which permits use, distribution and reproduction for non-commercial purposes, provided the original is properly cited and derivative works building on this content are distributed under the same license. 